\title{
Effect of thinning on biophysical soil properties of Cupressus lusitanica stand in Munessa forest, Ethiopia
}

\author{
Yonas Yohannes* \\ *Ethiopian Environment and Forest Research Institute, PO Box 24536, code 1000, \\ Addis Ababa, Ethiopia.
}

\begin{abstract}
Forest management practices such as thinning can dramatically change the microenvironment and thereby affect the physicochemical and soil microbiological properties. The aim of this research was to determine the effect of thinning on soil physicochemical properties and microbial biomass under Cupressus lusitanica plantation at Munessa forest. The experiment was carried out in a fenced stand treated differently (thinned and unthinned plots) with a completely randomized design. In each plot, 20 sampling spots were randomly selected for soil sample collection from 0 to $10 \mathrm{~cm}$ and 10 to $25 \mathrm{~cm}$ depth. Independent t-test was used to compare effects of thinning on biophysical properties of the soil. Results showed that soil organic carbon (SOC) and total nitrogen varied significantly between treatments. SOC concentration was generally lower at the soil depth of 0-10 to 10$25 \mathrm{~cm}$. The concentrations of microbial biomarker used as a proxy for microbial biomass assessment were $22 \%$ larger in thinned stands. Soils under the thinned stand contained larger concentration of arbuscular mycorrhizal fungi biomarker. The two forest stands were established at the same time with the same stocking and hence differences in soil quality could be possibly resulted from management intervention. These findings showed that Cupressus thinning could enhance biomass accumulation and organic $\mathrm{C}$ input to the soil.
\end{abstract}

Keyword: Biomarker, Microbial Biomass, Phospholipids, Plantation, Soil organic carbon

DOI: https://dx.doi.org/10.4314/ejst.v12i3.4

*Corresponding author: yonyoh4@gmail.com; Cellphone: +251911638127 


\section{INTRODUCTION}

The 2015 global forest resource assessment (FRA) report indicated that, during the past thirty years the world's forest area has declined from 4.1 billion ha to just under 4 billion ha, a decrease of 3.1 percent (FAO, 2016). It is the natural forest area that is decreasing. The report specified that planted forest area has increased by over 105 million ha since 1990 and accounted for $7 \%$ of the world's forest area. The share of the plantation area in Africa is the lowest among all the continents. Ethiopia has one of the longest forest plantation histories in Africa. The real planting of exotic tree species commenced 110 year ago with the introduction of Eucalyptus globules (Pohjonen and Pukkala, 1990). However, large-scale industrial plantations started during the Derge regime in the late 1970s. The current total area estimate is about 1 million ha (MEFCC, 2017). The majority of the plantations are covered by exotic tree species mainly Eucalyptus species (58\%) and Cupressus lusitanica (29\%) of the total area.

Plantation forest needs to be conscientiously managed to enhance stand quality and maintaining ecosystem function and processes. Management to increase overall ecosystem function and accelerate the accumulation of carbon for reserve in a plantation forest requires basic scientific exploration. Forest management practices and other disturbances alter microbial community, size of soil organic carbon, as well as the soil properties, by changing microenvironment condition (Jandl et al., 2007). For example, a tending operation such as thinning is typically used to increase the tree-bole volume of usable-sized trees and this can be one of the responsible factors for the largest gain in productivity over unmanaged plots. Such stand management is also expected to influence the environmental condition beneath the existing canopy, soil microclimate, and root dynamics (Da-Lun et al., 2010).

Thinning changes the plant community from a high-density forest to an open canopy. The opening of the canopy, due to the removal of a certain number of trees, is an important practice for the management of forests. These activities bring change in stand structure and herbaceous community. It results in important modifications of the microclimatic conditions that influence the ecophysiological functioning of trees and belowground components and it also influences soil-water relationships (Aussenac and Granier, 1988; Grayston and Renneberg, 2006).Thinning 
increases the risk of erosion (Carter et al., 2006) and changes in soil moisture (Grace et al., 2006). Despite the numerous investigations on the impact of thinning on soil properties and microbial biomass, there is inconsistency regarding the impact of thinning on soil biophysical properties. Other studies showed that thinning positively affected soil properties and microbial biomass (Hu and Zhu, 1999; Grady and Hart, 2006; Hwang and Son 2006; Chen et al., 2015) or no change in the respective parameters (Tan et al., 2008; Jang et al., 2016). Other reports show opposite effect of thinning on the soil properties and microbial biomass (Baena et al., 2013; Zhou et al., 2015). Thinning improved soil microbial quantity, enzyme activity, total porosity, available nutrients and soil fertility but reduced soil bulk density after 2-year thinning (Zhang et al., 2001).

Cupressus lusitanica a fast-growing evergreen conifer with high timber quality, is widely planted species in Ethiopia. The Munessa forest is one of the largest plantation forests established in the 1970s in Ethiopia. It covers about 6973 ha of which Cupressus lusitanica was the dominant planted tree species that accounted for $62.5 \%$ of the total plantation area (Tesfaye Teshome and Petty, 2000). Cupressus lusitanica plantation in the Munessa forest is typically used for industrial timber production. With the exception of weeding there is no other tending operation carried out throughout the rotation periods. Previous studies in Munessa forest have focused on water use efficiency (Masresha Fetene and Beck, 2004), root biomass and soilplant water dynamics (Fritzsche et al., 2006), soil chemistry (Mulugeta Lemenih et al., 2004) on Cupressus lusitanica plantation. Yeshanew Ashagire et al. $(2003,2005)$ have conducted research on the impact of forest conversion in relation to biogeochemical processes in the same forest. However, knowledge of forest management such as the impact of thinning on the biophysical properties of soil in Munessa forest does not exist. Understanding the variations in soil properties and microbial community is crucial for evaluating the stability of the soil organic pool and the sustainability of forest production following a thinning treatment. Therefore, in the present study, an attempt was made to determine the effects of thinning on soil physical, chemical and microbial properties in a thinned and unthinned control plots of Cupressus lusitanica stand found in Munessa forest, Ethiopia. 


\section{MATERIALS AND METHODS}

\section{Study site}

The study area is found in part of the forest stands of the Munessa forest $\left(7^{\circ} 25^{\prime} 44^{\prime \prime} \mathrm{N}\right.$ longitude and $38^{\circ} 51^{\prime} 05^{\prime \prime} \mathrm{E}$ latitude), located in Oromia Regional State, West Arsi zone, Ethiopia. The study stand was previously planted with Pinus patula. The slope is gentle and the elevation of the study plots is $2126 \mathrm{~m}$ above sea level. Eight-year meteorological records (2001-2009) in the study area has shown that the mean annual rainfall was $1144 \mathrm{~mm}$ and the mean annual temperature was $15{ }^{\circ} \mathrm{C}$ (Strobl, 2012). Though the area has been reported to receive a bimodal rain fall (Fritzsche et al., 2006), the data from the past eight years suggest lack of a clear demarcation for the short and long rainy seasons (Figure 1). The soil texture is predominately clay evolved from volcanic parent material and was classified as Mollic Nitisols.

\section{Study design}

Two experimental fenced plots were selected in which they were $50 \mathrm{~m}$ apart from each other and were uniform with regard to site characteristics. The planted trees are 5 years old. In January 2008, selective thinning has been done in one of the fenced areas by removing the competitors' trees next to trees assigned as a potential crop. No thinning operation was carried out on the other fenced area and was considered as a control. After thinning the number of trees left in the thinned plot was 98 as compared to 144 in the control plot.

\section{Soil sampling and preparation}

Core soil samples (cylindrical steel core with $4.0 \mathrm{~cm}$ diameter) were obtained separately in triplicate from $0-10$ and $10-25 \mathrm{~cm}$ depths. Soil sampling was performed within each forest plot at 20 randomly selected sample locations. Samples were obtained from 0-10 cm and $10-25 \mathrm{~cm}$ soil depth separately. The soil samples were then mixed to form the composite sample. Three replicates from each composite soil sample were used for further analysis. Immediately after collection the soil samples were sieved with $2 \mathrm{~mm}$ mesh size and all visible fine roots were picked out. After homogenization of each soil sample, aliquots (c. $2 \mathrm{~g}$ ) were taken for organic $\mathrm{C}$ and total organic $\mathrm{N}$ analysis. After air-drying, soil samples were finely ground with a steel ball mill (Mixer Mill, Retsch MM 200) and dried overnight at $105{ }^{\circ} \mathrm{C}$. Likewise, directly after homogenization of the 
soil, subsamples of about $10 \mathrm{~g}$ were collected separately for phospholipids fatty acid (PLFA) and neutral lipid fatty acid (NLFA) analysis. After removing all visible plant materials, the soil samples were then packed in small glass vials and kept frozen until analyzed.

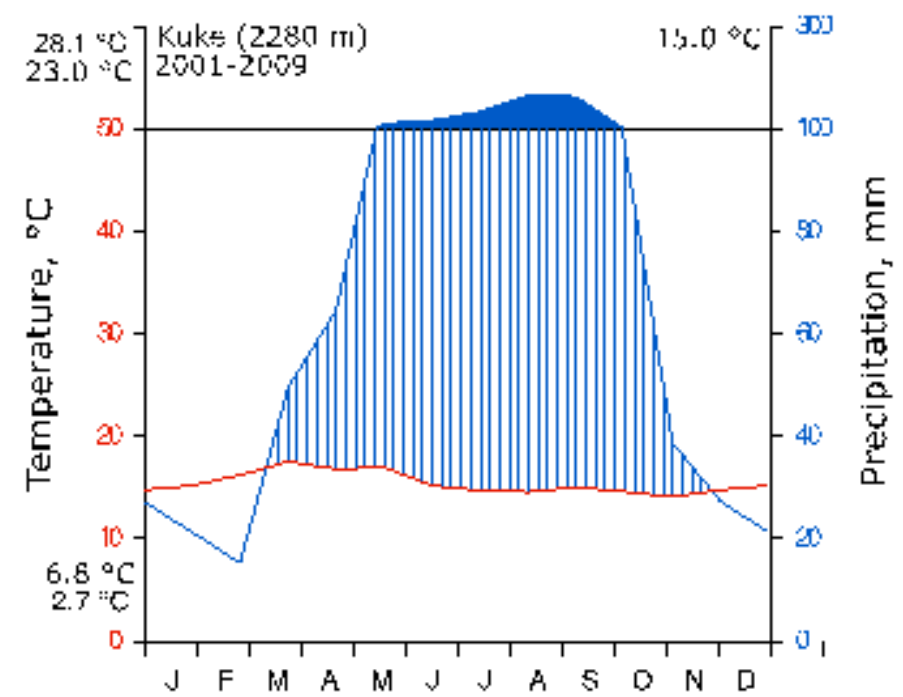

Figure 1. Walter-type climate diagram of the research area (eight-year averages from 2001 to 2009 at Kuke field station).

\section{Laboratory analysis}

Air dried soil samples was used to determine texture by the pipette method (Gee and Bauder, 1986). Soil $\mathrm{pH}$ was analyzed potentiometrically in $1 \mathrm{M}$ $\mathrm{KCl}[1: 2.5(\mathrm{~m} / \mathrm{v})]$. Cation exchange capacity (CEC) was determined with the $\mathrm{BaCl}_{2}$ compulsive exchange method (Gillman and Sumpter, 1986). Soil organic carbon and nitrogen contents were analyzed using a Vario EL III elemental analyzer (Elementar Analysensysteme GmbH, Germany). Lipid fatty acid extraction was carried out using frozen soil samples $(1.5 \mathrm{~g})$ extracted overnight with a chloroform-methanol citrate buffer mixture (1:2:08) by the modified method described by Bligh and Dyer (1959). The fatty acid 19:0 (nonadecanoic acid methyl ester) was added to the samples as an internal standard. Lipids were separated into neutral, glyco-, and phospholipids using solid phase extraction with silicic acid column (Bond Elut LRC-Si, Varian Agilent Technologies, Santa Clara, CA). Thereafter, 
the neutral and phospholipids were subjected to a mild-alkali methanolysis, and the resulting fatty acid methyl esters were separated by gas chromatography using an Agilent 7890A GC-MS (Varian Agilent Technologies, Santa Clara, CA). The fatty acids were quantified by comparison of the peak areas with those of the standard peak. Standard nomenclature was used to refer to the PLFAs according to the designation described in Zelles (1999). Phospholipid fatty acids i15:0, a15:0, i16:0, 18:1 $17 \mathrm{c}$ and cy19:0 were used to represent bacterial biomass (Zelles,

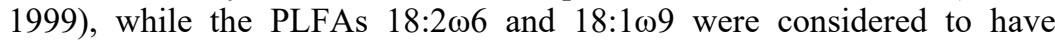
fungal origin (Zelles, 1997). The neutral lipid fatty acid (NLFA 16:1 $\omega 5$ ) was used as a marker fatty acid for AM fungi (Olsson and Johansen, 2000).

\section{Data analysis}

Data were expressed as means of three replications for each forest plot and soil depth. Mole percents of individual fatty acids were used as an input values for microbial biomass analysis. The concentrations of each fatty acids (nmol g $\mathrm{g}^{-1}$ dry soil) were calculated based on the peak areas to an analytical standard peak (19:0, Sigma Chemical Co., St. Louis, MO, USA). These concentrations were used in all statistical analyses. To assess the significance of all data between the thinned and control plots, a mean separation test was used. Normality of treatment group means was assessed using the Shapiro-Wilk test and homogeneity of variance among means using Levene's Test. Differences were considered significant at the $p<0.05$ level. All graphing and statistical analysis was performed using SigmaPlot version 11 (Systat Software Inc., San Jose, CA, USA).

\section{RESULTS AND DISCUSSION}

\section{Soil physicochemical properties}

The changes in physicochemical properties at thinned and adjacent control plots are presented in Table 1. The $\mathrm{pH}$ was slightly acidic at both experimental plots. Although on average, the change of soil $\mathrm{pH}$ between the two plots was not significant, the mean soil $\mathrm{pH}$ at a depth of $0-10 \mathrm{~cm}$ was lower at the thinned plot (6.0) than control plots (6.3). In contrast, from a depth of $10-25 \mathrm{~cm}$ soil $\mathrm{pH}$ values tended to be similar in both forest plots (Table 1). Similarly, there was no significant difference in cation exchange capacity (CEC) between the two experimental plots. However, 
corresponding values were higher under thinned forest plots which is mainly driven by differences in exchangeable $\mathrm{Ca}++$. Unlike soil $\mathrm{pH}$, there was significant difference in CEC between soil sampling depth. In both forest plots, CEC of the subsoil $(10-25 \mathrm{~cm})$ was significantly lower than the topsoil $(0-10 \mathrm{~cm})$, with an overall decline of about $30 \%$ (Table 1 ).

From $0-10$ to $10-25 \mathrm{~cm}$ soil depth the SOC concentration decreased significantly $(P<0.05)$. Concurrently to the decline in SOC with soil depth, the CEC decreased as well, showing the impact of soil organic matter on exchangeable nutrients in these forest plot. The results of one-way ANOVA showed that larger SOC concentrations under thinned plot was observed in the $0-10 \mathrm{~cm}$ soil layer than in the unthinned plot, but the values were not statistically significant $(p<0.05)$. Furthermore, a similar trend was also observed in TN from the depth (Table 1). However, TN from a soil depth of 10-25 cm was significantly different between the twoforest plots $(P<0.05)$ where the thinned plot soil had higher concentrations than samples taken from the control plot (Table 1).

Forest management intervention can cause significant impact in the soil quality, which can lead to changes in soil physical attributes. After thinning operation, a forest stand produces un-harvested residues such as fallen leaves, shoots, and dying and dead roots that can be used as a nutritive substrate for soil microorganisms. Thinning also creates opening gaps and these gaps promotes solar radiation, soil temperature, and soil moisture (Scharenbroch and Bockheim, 2007) that improves living conditions for soil microbes. Furthermore, thinning treatment could bring change in understory species and functional diversity in gaps (Ares et al., 2010). Therefore, changes in microclimate, soil resource availability as well as plant community composition due to thinning are expected to affect the structure and function of microbial communities (Chatterjee et al., 2008) and consequently affecting microbial regulation on the soil carbon process (Wu et al., 2019). In the present study, the plots were located close to each other and trees were initially planted at the same time and with the same stocking and hence differences in belowground properties could be possibly as the result of management intervention (thinning). This notion emanates from the observation that larger aboveground biomass from individual potential crop trees. 
Table 1. Basic characteristic of the soils from 0-10 cm and $10-25 \mathrm{~cm}$ soil depth of thinned and unthinned plots.

\begin{tabular}{|c|c|c|c|c|c|c|c|c|}
\hline \multirow{2}{*}{$\begin{array}{l}\text { Plot/ } \\
\text { depth }\end{array}$} & Sand $^{*}$ & Silt $^{*}$ & Clay $^{*}$ & $\mathbf{C}^{*}$ & $\mathbf{N}^{*}$ & \multirow[t]{2}{*}{$\mathbf{p H} \mathbf{H}^{\S}$} & \multirow{2}{*}{$\frac{\mathrm{CEC}^{\mathrm{g}}}{\mathrm{mmol}_{(+)} \mathrm{kg}^{-1}}$} & \multirow{2}{*}{$\begin{array}{c}\mathbf{B S}^{* *} \\
\%\end{array}$} \\
\hline & \multicolumn{3}{|c|}{$-\mathbf{g ~ k g}^{-1}-$} & \multicolumn{2}{|c|}{$-\mathbf{g ~ k g}^{-1}-$} & & & \\
\hline \multicolumn{9}{|c|}{ Thinned plots } \\
\hline $0-10 \mathrm{~cm}$ & $210 \pm 15$ & $395 \pm 62$ & $395 \pm 67$ & $114 \pm 27^{a}$ & $10.2 \pm 2.3^{\mathrm{a}}$ & $6.0 \pm 0.5^{\mathrm{a}}$ & $638 \pm 92^{\mathrm{a}}$ & 100 \\
\hline $10-25 \mathrm{~cm}$ & $189 \pm 8$ & $371 \pm 65$ & $440 \pm 70$ & $39 \pm 15^{\mathrm{b}}$ & $4.3 \pm 1.6^{\mathrm{b}}$ & $5.7 \pm 0.6^{\mathrm{a}}$ & $449 \pm 69^{b}$ & 100 \\
\hline \multicolumn{9}{|c|}{ Unthinned plots } \\
\hline $0-10 \mathrm{~cm}$ & $203 \pm 20$ & $376 \pm 20$ & $421 \pm 20$ & $90 \pm 23^{\mathrm{a}}$ & $8.8 \pm 2.2^{\mathrm{a}}$ & $6.3 \pm 0.5^{\mathrm{a}}$ & $568 \pm 24^{\mathrm{a}}$ & 100 \\
\hline $10-25 \mathrm{~cm}$ & $190 \pm 26$ & $329 \pm 7$ & $481 \pm 27$ & $21 \pm 6^{\mathrm{b}}$ & $2.0 \pm 0.5^{\mathrm{c}}$ & $5.7 \pm 0.7^{\mathrm{a}}$ & $447 \pm 74^{\mathrm{b}}$ & 100 \\
\hline
\end{tabular}


In the same experimental plots, Zeleke Asaye (2011) identified significantly higher annual fine root biomass production in the thinned plot (554-603 $\mathrm{g} \mathrm{m}^{-2}$ ) as compared to the unthinned plot (327-364 $\left.\mathrm{g} \mathrm{m}^{-2}\right)$. Above and belowground fine litter are a major component of biomass (Clark et al., 2001); larger input of the former materials under the experimental plots in the thinned part was also expected and this could probably contribute to larger carbon input. Two years after thinning treatment, Hwang and Son (2006) found out mean SOC concentrations $\left(\mathrm{g} \mathrm{kg}^{-1}\right)$ for pitch pine and Japanese larch plantations of 39.6 and 58.8 for the control and 44.0 and 63.4 for the thinned plot. In a forest ecosystem, inorganic matter assimilation is performed by fine roots (Yunusa et al., 2012) and they also function as a major source of organic matter in the soil (Du and Fang, 2014).

\section{Soil microbial biomass}

The relative abundance of individual fatty acid profiles extracted from soil samples under the experimental plot is shown in Figure 2. The normal

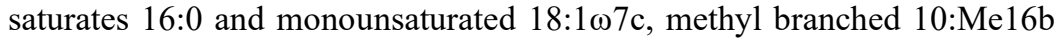
and branched chain saturated i15 were the most abundant PLFAs, accounting for $54 \%$ of the total concentration. Monounsaturated 16:1 1 , 18:1 19 , and Cyclopropyl fatty acid cy 19:0 were formed the second most predominant group (24\%). Branched-chain saturates (a15 and i16), monounsaturated 16:1 155 and methyl branched 10:Me16a were 19\% of the total concentration. $18: 2 \omega 6$ and $16: 1 \omega 9$ were $3 \%$ of the total PLFA concentration. There are no major differences in mole percentage of individual PLFAs between the two plots, which indicates the lack of noticeable effects of soil origin and land use history.
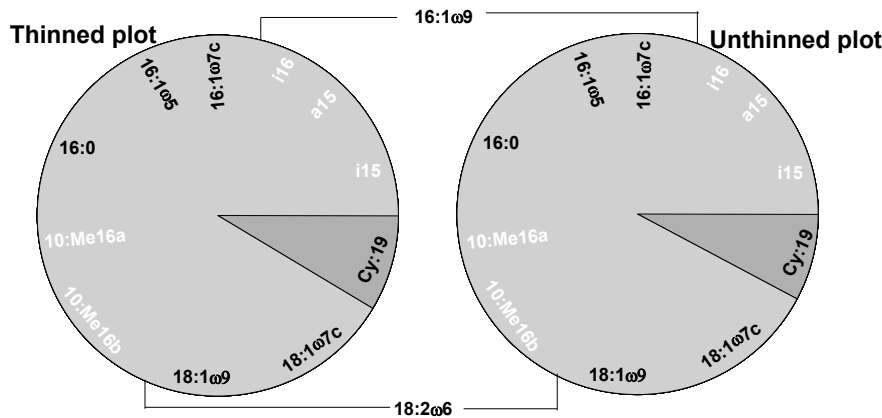

Figure 2. Proportion of individual fatty acids under the two-forest plots 


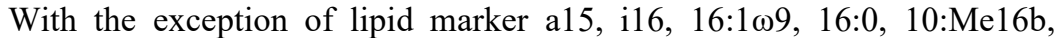

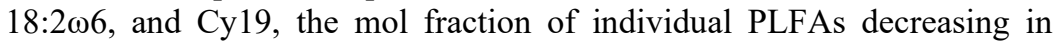
proportional abundance with soil depth. However, in terms of PLFA concentration, each lipid marker followed the patterns of soil organic $\mathrm{C}$ and TN content, and decreased from $0-10$ to $10-25 \mathrm{~cm}$ soil depth (Table 2). At $0-10 \mathrm{~cm}$ soil depth, total PLFA concentration tended to be larger in soil under managed plot $\left(271.5 \pm 39.1 \mathrm{nmol}^{\text {PLFA g }} \mathrm{g}^{-1}\right.$ dry soil $)$. The soil under unmanaged plot exhibited less concentration (166.2 $\pm 57.1 \mathrm{nmol} \mathrm{PLFA} \mathrm{g}^{-1}$ dry soil). From the depth 10-25 $\mathrm{cm}$, PLFAs concentration under the managed plots (136.1 \pm 9.3 nmol PLFA g ${ }^{-1}$ dry soil) had contained larger concentration than the unmanaged ones $\left(76.5 \pm 6.4\right.$ nmol PLFA g ${ }^{-1}$ dry soil).

Table 2. Proportion of PLFA profiles, expressed as mol\% in soil from $0-10 \mathrm{~cm}$ and $10-25 \mathrm{~cm}$ soil depth thinned and unthinned plot

\begin{tabular}{|c|c|c|c|c|}
\hline \multirow{2}{*}{ PLFA } & \multicolumn{2}{|c|}{ Thinned plot } & \multicolumn{2}{|c|}{ Unthinned plot } \\
\hline & $0-10 \mathrm{~cm}$ & $10-25 \mathrm{~cm}$ & $0-10 \mathrm{~cm}$ & $10-25 \mathrm{~cm}$ \\
\hline i15 & $10.22(0.90)$ & $10.15(1.30)$ & $9.32(1.06)$ & $8.12(0.72)$ \\
\hline a15 & $5.01(1.14)$ & $5.09(1.16)$ & $4.63(0.47)$ & $4.36(0.53)$ \\
\hline i16 & $4.97(0.35)$ & $5.61(0.37)$ & $5.05(0.37)$ & $4.73(0.30)$ \\
\hline $16: 1 \omega 9$ & $1.41(0.13)$ & $1.53(0.09)$ & $1.12(0.39)$ & $1.02(0.44)$ \\
\hline $16: 1 \omega 7 \mathrm{c}$ & $7.47(0.49)$ & $6.47(1.49)$ & $7.66(0.99)$ & $6.69(0.72)$ \\
\hline $16: 1 \omega 5$ & $4.70(0.61)$ & $4.31(0.84)$ & $4.85(0.54)$ & $4.43(0.67)$ \\
\hline $16: 0$ & $16.95(1.87)$ & $17.23(1.11)$ & $18.45(1.76)$ & $19.00(2.54)$ \\
\hline 10:Me16a & $3.89(0.37)$ & $3.42(0.76)$ & $3.95(0.21$ & $3.74(0.07)$ \\
\hline 10:Me16b & $12.81(1.19)$ & $14.09(1.82)$ & $11.99(2.89)$ & $12.34(1.36)$ \\
\hline $18: 2 \omega 6$ & $1.82(0.61)$ & $2.24(0.56)$ & $2.34(0.64)$ & $2.86(0.38)$ \\
\hline $18: 1 \omega 9$ & $8.38(1.14)$ & $8.12(1.31)$ & $8.89(0.04)$ & $9.95(0.52)$ \\
\hline $18: 1 \omega 7 \mathrm{c}$ & $13.79(0.77)$ & $12.65(0.67)$ & $14.00(0.32)$ & $14.30(0.66)$ \\
\hline Су19 & $8.58(0.26)$ & $9.09(1.45)$ & 7.77 (1.99) & $8.47(2.43)$ \\
\hline Total PLFAs* & $271.5(39.1)$ & $136.1(9.3)$ & $166.2(57.1)$ & $76.5(6.4)$ \\
\hline
\end{tabular}

Values are Averaged mol\% of individual fatty acids (SD in parenthesis, $n=3$ );

* stands for Total amounts of PLFAs in nmol g-1 dry weight of soil

At a depth of $0-10 \mathrm{~cm}$ soil layer, the biomass of fungal marker indicator

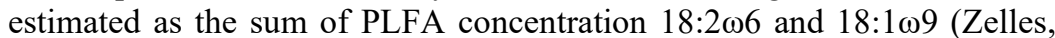
1997) tended to be larger in soil under managed plot (27.7 nmol fungal PLFA g-1 dry soil). The corresponding value for unmanaged plot was found to be 18.7 nmol fungal PLFA g-1 dry soil). At the same soil depth, biomass of bacterial marker indicator estimated from PLFA concentration 
i15:0, a15:0, i16:0, 18:107c and cy19:0 (Zelles, 1999) were found to be larger in soil under the thinned plot (115.6 nmol bacterial PLFA g ${ }^{-1}$ dry soil) and $67.7 \mathrm{nmol}$ bacterial PLFA g ${ }^{-1}$ dry soil (unthinned plot). From the depth of $10-25 \mathrm{~cm}$ soil layer, biomass of fungal and bacterial marker indicators PLFAs concentration was found 14.1 and 58 nmol PLFA g ${ }^{-1}$ dry soil vs. 9.8 and $30.6 \mathrm{nmol}_{\text {PLFA g }}{ }^{-1}$ dry soil, for managed vs. unmanaged plot respectively (Table 2). At both soil depths, the thinned plot contained larger concentration of NLFA16:1 $\omega 5$ (arbuscular mycorrhizal fungi biomarker) with values of 3.6 and $1.9 \mathrm{NLFA} \mathrm{g}^{-1}$ dry soil vs. 2.1 and 1.1 NLFA $\mathrm{g}^{-1}$ dry for thinned vs. unthinned plot respectively.

The reduction of stand densities and opening canopy encourage the establishment of understoryy vegetation and functional diversity in gaps (Lindh and Muir, 2004; Ares et al., 2010). Although I didn't attempt to enumerate the understory vegetation in a scientific manner, the area of the managed plot had clear influence on the abundance of the understory vegetation but the opposite was observed under the control plot (personal observation). Understory plant can have important and diverse effects on quality of substrate inputs into the soil through changing litter inputs and altering the soil microclimate (Zhao et al., 2018). As a consequence of these changes, the composition of the soil microbial community may be altered or microbial activities may increase (Mikola et al., 2000). In the present study forest stand, Zeleke Asaye (2011) found out higher production and turnover rate of fine roots in thinned plot than control plot. Fine root biomass production and its relationship to aboveground biomass have been studied by various authors (see Leppälammi-Kujansuu et al., 2014 and reference cited there). This could be a potential explanation for the differences between the two experimental plots in microbial biomass. Carbon input through aboveground litter and belowground input through fine root production and turnover and associated microbial activity are well-documented processes in the carbon and nutrient cycling of forest ecosystems (Majdi and Kangas, 1997). Based on the present finding, one could expect that belowground and/or aboveground litter input might increase soil microbial activity and induce changes of the microbial biomass between the thinned and control plot. Positive relations between fine roots and microbial biomass parameters have been frequently reported (e.g. by Wardle, 1992; Lee and Jose, 2003). Similarly, Hwang and Son (2006) found larger fine root input to the soil after thinning and argued that this was enough organic matter input to offset potential losses of soil OC by soil respiration. On the other hand, the declining PLFAs concentration 
with soil depth is the result of decline in resource availability, predominately a function of decline in organic matter and is a common pattern across many ecosystems (Feng et al., 2003).

\section{CONCLUSION}

Forest management practices such as thinning operations are necessary parts of forestry. The present study has showed that soil chemical and biological properties are changed by forest management intervention. At both soil sampling depth, the thinned plot had higher C, N, CEC and microbial concentration than the control plot that could be resulted from larger above ground and belowground biomass accumulated by individual potential crop trees. The opening of forest stands due to thinning also favor the flourishing of understory biomass in the managed plot than the control plot. In addition, the stump roots left at thinned plot together with understory vegetation could have contributed the differences in the chemical and biological properties of the soil. This increased fertility of the soil could provide a valuable nutrient supply to the succeeding forest stand, particularly if it is given proper protection. From these results, it can be concluded that thinning operation has a positive effect on soil quality in Cupressus plantation in the Munessa forest, Ethiopia. However, information from the present study will aid in understanding the general and sites specific responses of soil chemical and microbial biomass properties to thinning treatment. The issue involved in understanding the effect of thinning on soil quality should be more holistic, and it needs further investigation using a longer-term study.

\section{ACKNOWLEDGEMENTS}

Funding for this research was provided by Deutsche Forschungsgesellschaft (DFG). The author wishes to thank Ethiopian colleagues who participated in soil sample collection and the entire laboratory staff of Soil Science Institute, Gottfried Wilhelm Leibniz Universität, Hannover. 


\section{REFERENCES}

Ares, A., Neill, A. R and Puettmann, K. J. (2010). Understory abundance, species diversity and functional attribute response to thinning in coniferous stands. Forest Ecology and Management 260: 1104-1113.

Aussenac, G and Granier, A. (1988). Effects of thinning on water stress and growth in Douglas-fir. Canadian Journal of Forest Research 18: 100-105.

Baena, C.W., Andrés-Abellán, M., Lucas-Borja, M.E., Martínez-García, E., García-Morote, F.A., Rubio, E and López-Serrano, F.R. (2013). Thinning and recovery effects on soil properties in two sites of a Mediterranean forest, in Cuenca Mountain (South-eastern of Spain). Forest Ecology and Management 308: $223-230$.

Bligh, E.G and Dyer, W.J. (1959). A rapid method of total lipid extraction and purification. Canadian Journal of Biochemical Physiology 37: 911-917.

Carter, E.A., Rummer, R.B and Stokes, B.J. (2006). Evaluation of site impacts associated with three silvicultural prescriptions in an upland hardwood stand in northern Alabama, USA. Biomass and Bioenergy 30: 1025-1034.

Chen, X.L., Wang, D., Chen, X.,Wang, J., Diao, J.J., Zhang, J.Y and Guan, Q.W. (2015). Soil microbial functional diversity and biomass as affected by different thinning intensities in a Chinese fir plantation. Applied Soil Ecology 92: 35-44.

Clark, D.A., Brown, S., Kicklighter D.W, Chambers, J.Q., Thomlinson, J.R and Ni, J. (2001). Measuring net primary production in forests: concepts and field methods. Ecological Application 11: 356-370.

Da-Lun, T., Yuan-Ying, P., Wen-De, Y., Xi, F., Wen-Xing, K., Guang-Jun, W and Xiao-Young, C. (2010). Effects of thinning and litterfall removal on fine root production and soil organic carbon content in Masson pine plantations. Pedosphere 20 (4): 486-493.

Du, E and Fang, J. (2014). Linking belowground and aboveground phenology in two boreal forests in northeast China. Oecologia 176: 883-892.

FAO. (2016). The global forest resource assessment 2015: How are the world's forests changing? $2^{\text {nd }}$ ed. Food and Agriculture Organization of the United Nations, Rome, Italy.

Feng, Y., Motta, A.C., Reeves, D.W., Burmester, C.H., van Santen, E and Osborne, J.A. (2003). Soil microbial communities under conventional-till and no-till continuous cotton systems. Soil Biological and Biochemical 35: 1693-1703.

Fritzsche, F., Asferachew Abate, Masresha Fetene, Beck, E., Stephan, W and Guggenberger, G. (2006). Soil-plant hydrology of indigenous and exotic trees in an Ethiopian montane forest. Tree Physiology 26: 1043-1054.

Grace, J.M. III, Skaggs, R.W and Cassel, D.K. (2006). Soil physical changes associated with forest harvesting operations on an organic soil. Soil Science Society of America Journal 70 (2): 503-509. 
Grady, K.C and Hart, S.C. (2006). Influences of thinning, prescribed burning, and wildfire on soil processes and properties in southwestern ponderosa pine forests: A retrospective study. Forest Ecology and Management 234: 123-135.

Grayston, S.J and Renneberg, H. (2006). Assessing effects of forest management on microbial community structure in a central European beech forest. Canadian Journal of Forestry Research. 40: 1901-1907.

$\mathrm{Hu}$, J.W and Zhu, C.Q. (1999). The impacts of intermediate felling on forest environment. Journal of Northeast Forest University 27: 65-67.

Hwang, J and Son, Y. (2006). Short-term effects of thinning and liming on forest soils of pitch pine and Japanese larch plantations in central Korea. Ecological Research 21: 671-680.

Jandl, R., Lindner, M. Vesterdal, L. Bauwens, B. Baritz, R., Hagedorn, F., Johnson, D.W and Minkkinen, K.E. (2007). How strongly can forest management influence soil carbon sequestration? Geoderma 137: 253-268.

Jang, W., Page-Dumroese, D.S and Keyes, C.R. (2016). Long-term soil changes from forest harvesting and residue management in the northern Rocky Mountains. Soil Science Society of American Journal 80: 727-741.

Lee, K.H and Jose, S.B. (2003). Soil respiration, fine root production and microbial biomass in Cottonwood and Loblolly pine plantations along a $\mathrm{N}$ fertilization gradient. Forest Ecology and Management 185: 263-273.

Leppälammi-Kujansuu, J., Aro, L., Salemaa, M., Hansson, K., Kleja, D.B and Helmisaari, H.S. (2014). Fine root longevity and carbon input into soil from below- and aboveground litter in climatically contrasting forests. Forest Ecology and Management 326: 79-90.

Lindh, B.C and Muir, P.S. (2004). Understory vegetation in young Douglas-fir forests: Does thinning help restore old-growth composition? Forest Ecology and Management 192: 285-296.

Majdi, H and Kangas, P. (1997). Demography of fine roots in response to nutrient applications in a Norway spruce stand in southwestern Sweden. Ecoscience 4: 199-205.

Masresha Fetene and Beck, E. (2004). Water relations of indigenous versus exotic tree species, growing at the same site in a tropical montane forest southern Ethiopia. Trees 18: 428-435.

MEFCC (2017). National Forest Sector Development Program, Ethiopia. Volume I: Situation Analysis. Ministry of Environment, Forest and Climate Change (MEFCC), Addis Ababa, Ethiopia.

Mikola, J., Barker, G.M and Wardle, D.A. (2000). Linking Above-Ground and Below-Ground Effects in Autotrophic Microcosms: Effects of Shading and Defoliation on Plant and Soil Properties. Oikos 89(3): 577-587.

Mulugeta Lemenih, Olsson, M and Karltun, E. (2004). Comparison of soil attributes under Cupressus lusitanica and Eucalyptus saligna established on abandoned farmlands with continuously cropped farmlands and natural forest in Ethiopia. Forest Ecology and Management 195: 57-67. 
Olsson, P.A and Johansen, A. (2000). Lipid and fatty acid composition of hyphae and spores of arbuscular mycorrhizal fungi at different growth stages. Mycological Research 104: 429-434.

Pohjonen, V and Pukkala, T. (1990). Eucalyptus globulus in Ethiopian forestry. Forest Ecology and Management 36: 19-31.

Scharenbroch, B and Bockheim, J. (2007). Impacts of forest gaps on soil properties and processes in old growth northern hardwood-hemlock forests. Plant and Soil 294: 219-233.

Strobl, S. (2012). Analysis of the "nurse-tree effect" of natural and exotic shelter trees on the growth of the indigenous Podocarpus falcatus in an Ethiopian montane forest. Dissertation, University of Bayreuth, Bayreuth, Germany.

Tan, X., Chang, S.X., Comeau, P.G and Wang, Y. (2008). Thinning effects on microbial biomass, $\mathrm{N}$ mineralization, and tree growth in a mid-rotation fireorigin lodgepole pine stand in the lower foothills of Alberta, Canada. Forest Science 54: 465-474.

Tesfaye Teshome and Petty, J.A. (2000). Site index equation for Cupressus lusitanica stands in Munessa forest, Ethiopia. Forest Ecology and Management 126: $339-347$.

Wardle, D.A. (1992). A comparative assessment of factors which influence microbial biomass carbon and nitrogen levels in soil. Biological Review 67: 321-358.

Wu, R.; Cheng, X and Han, H. (2019). The effect of forest thinning on soil microbial community structure and function. Forests 10(4): 352.

Yeshanew Ashagrie, Wolfgang, Z and Guggenberger, G. (2005). Transformation of a Podocarpus falcatus dominated natural forest into a monoculture Eucalyptus globulus plantation at Munesa, Ethiopia: Soil organic C, N and S dynamics in primary particle and aggregate-size fractions. Agriculture, Ecosystems \& Environment 106: 89-98.

Yeshanew Ashagrie, Wolfgang, Z., Guggenberger, G and Demel Teketay. (2003). Changes in soil organic carbon, nitrogen and sulphur stocks due to the conversion of natural forest into tree plantations (Pinus patula and Eucalyptus globulus) in the highlands of Ethiopia. World Resource Review 15: 462-482.

Yunusa, I.A.M., Zolfaghar, S., Zeppel, M.J.B., Li, Z., Palmer, A.R and Eamus, D. (2012). Fine root biomass and its relationship to evapotranspiration in woody and grassy vegetation covers for ecological restoration of waste storage and mining landscapes. Ecosystems 15: 113-127.

Zeleke Asaye (2011). Fine root production and soil respiration in managed and unmanaged stands of Cupressus lusitanica in Munessa Forest, Southern Ethiopia. M. Sc. Thesis, Hawassa University, Hawassa, Ethiopia.

Zelles, L. (1997). Phospholipid fatty acid profiles in selected members of soil microbial communities. Chemosphere 35: 275-294.

Zelles, L. (1999). Fatty acid patterns of phospholipids and lipopolysaccharides in characterization of microbial communities in soil: a review. Biology and Fertility of Soils 29: 111-129. 
Zhang, L., Dawes, W.R and Walker, G.R. (2001). Response of mean annual evapotranspiration to vegetation changes at catchment scale. Water Resource Research 37: 701-708.

Zhao, F., Wang. J., Zhang, L., Ren, C., Han, X., Yang, G., Doughty, R and Deng, J. (2018). Understory Plants Regulate Soil Respiration through Changes in Soil Enzyme Activity and Microbial C, N, and P Stoichiometry Following Afforestation. Forests 9: 436 doi:10.3390/f9070436.

Zhou, X., Zhou, Y., Zhou, C., Wu, Z., Zheng, L., Hu, X., Chen, H and Gan, J. (2015). Effects of cutting intensity on soil physical and chemical properties in a mixed natural forest in southeastern China. Forests 6: 4495-4509. 